تأثير استخدام تدريبات المنافسة على اداء بعض المهارات المندمجة للاعبى كرة القدم "حسن سعد مساعد المجمد" (20)

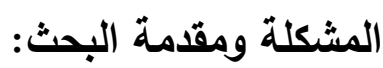

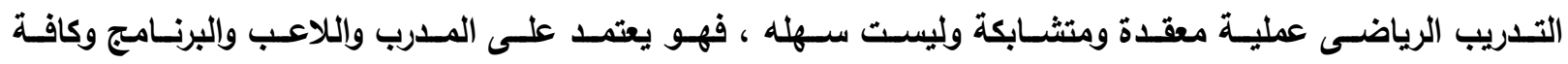

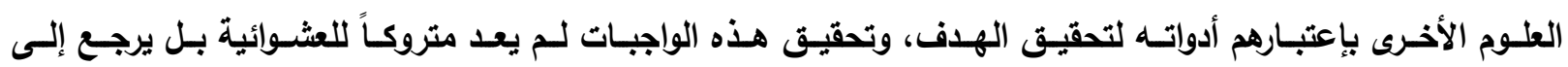

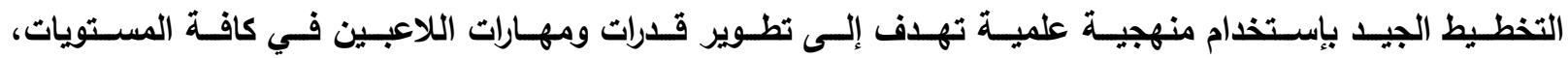

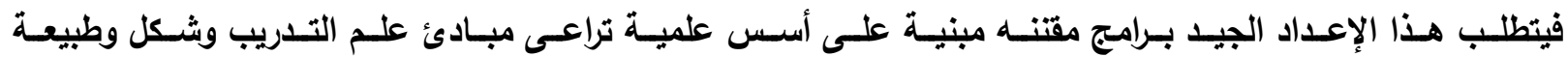

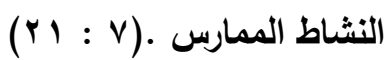

ويذكر "علي البيك واخرون (9 . . بم)" إن تخطيط التدريب الرياضي يلعب دورا كبيرا وهامـا في عملية التدريب

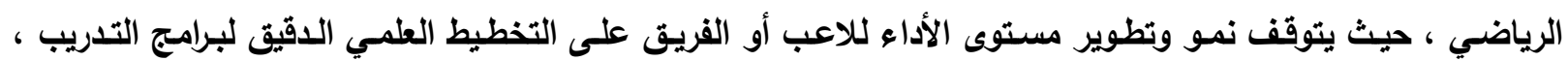

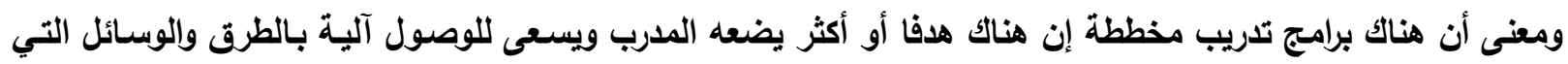
تحقق هذا الهلف.

فتخطيط التدريب عبارة عن الإجراءات الضرورية المدددة والمدونسه التي يضعها ، ويلتزم بها المدرب لتتميـة

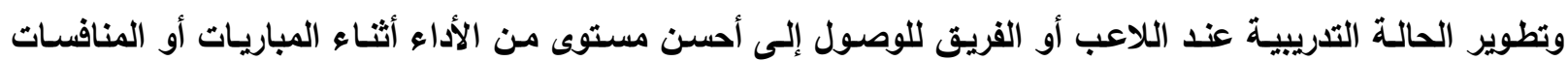
(الفورمة الرياضية).

فالفورمة الرياضية تغني الحالة المثلى والمستقرة للاعب أو الفريق لتحقيق الحد الأقصى من المستويات والاداءات

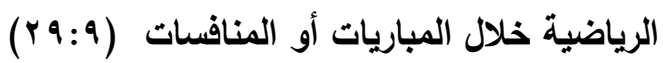

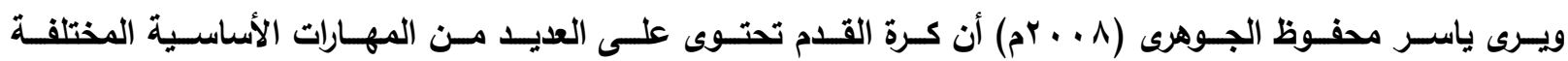

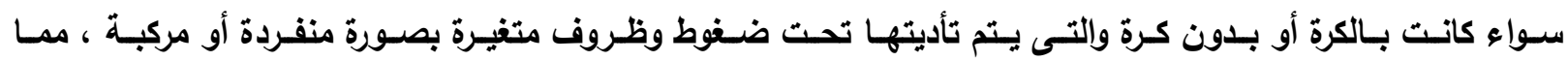

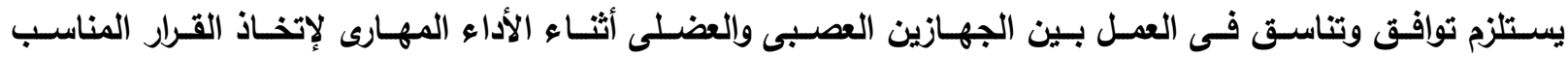

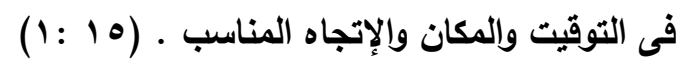

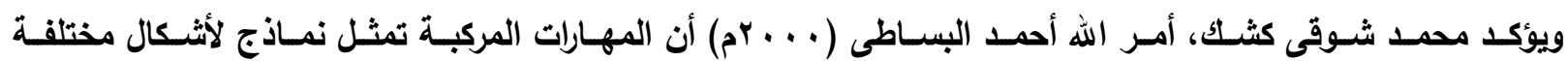

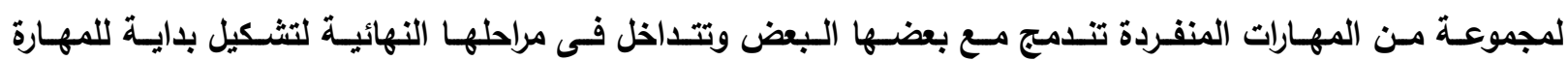

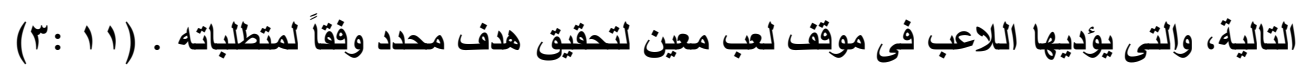

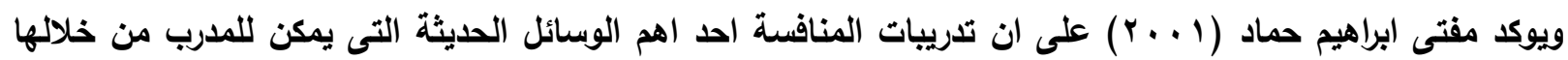

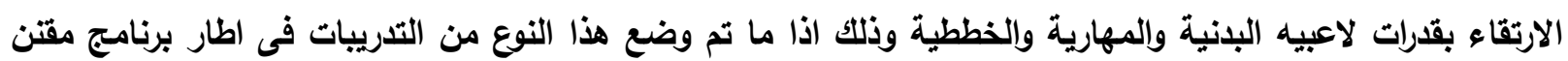

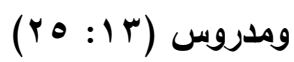


كما يرى حسن ابو عبده(0 1 + ) ان تدريبات المنافسة تعد وسيلة هامة للارتقاء بالنواحى المارية والخطيطة للاعبى كرة

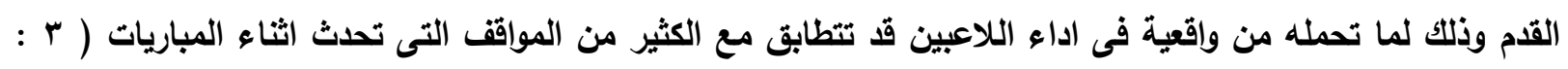

ويرى حنفى مختار (9 9 ( ) ان تدريبات المنافسة من اهم انواع التمرينات والتى ترفع من مستوى كفاءة الاداء

للاعب وتصل به الى الحالة التدريبية (VV:0)

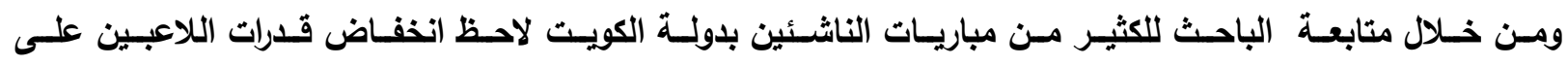

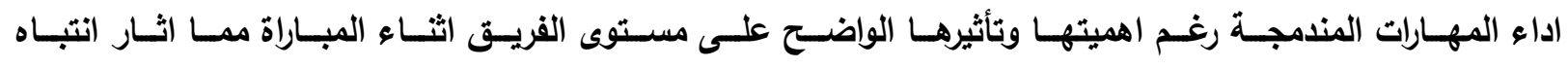

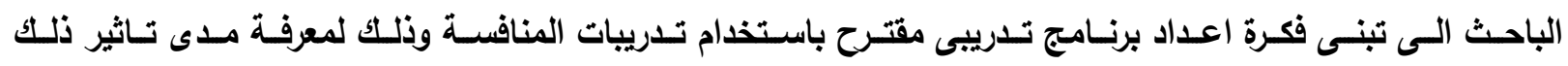
البرنامج وما يحتويه من تدريبات منافسة على مستوى اداء اللاعبين لتلك المهارات المندمجة اثناء المباريات هدف البحث: : n

تصميم برنامج تدريبى مقترح بإستخلام تدريبات المنافسة ومعرفة مدى تاثيره على اداء اللاعبين لبعض المهارات المندمجة في كرة القدم

فروض البحث :

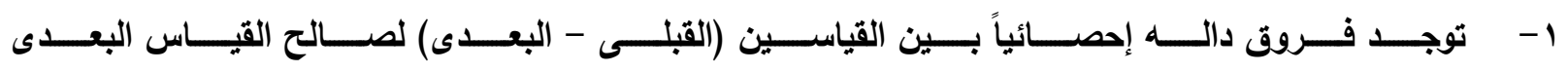

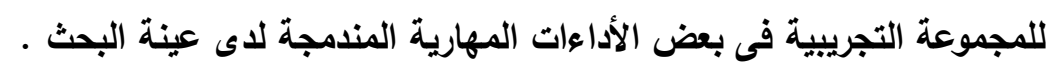

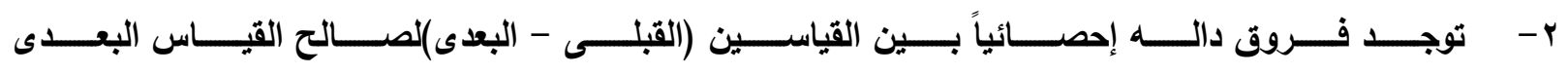

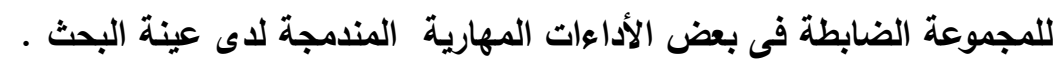

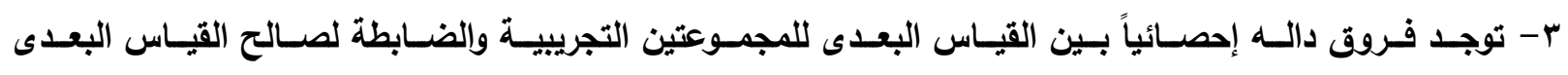

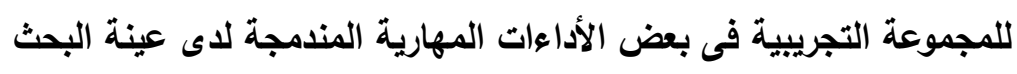

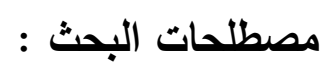
تدريبات المنافسة:-

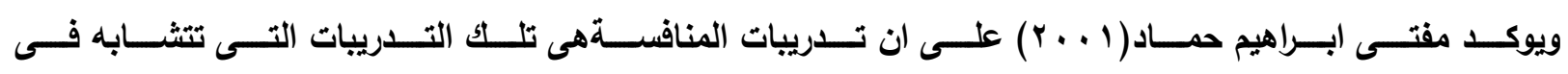

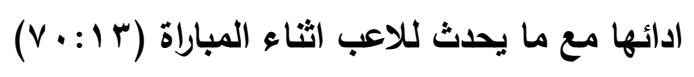

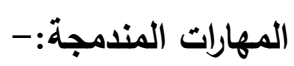

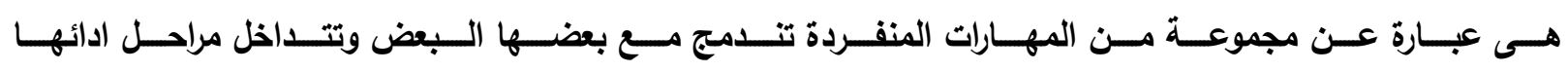

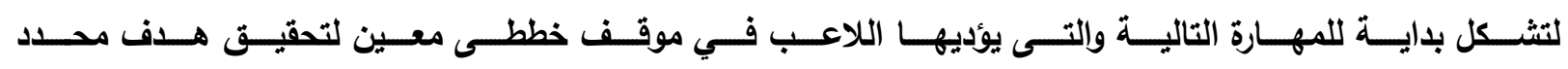
وفقا لمتطلباته ( ع ا: . ع ؛ ) الاراسات السابقة :

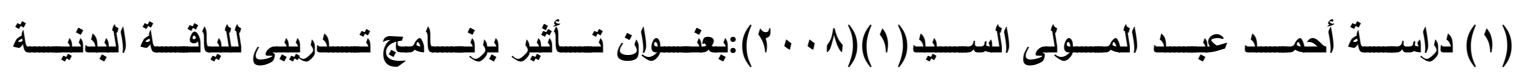

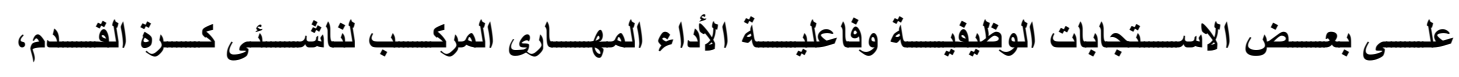




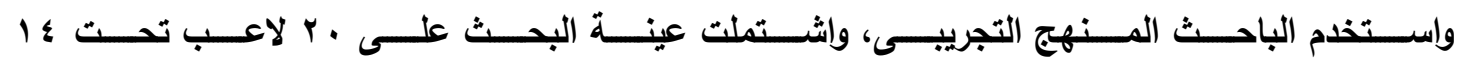

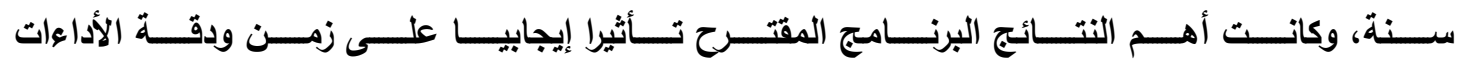
المهارية المركبة وعلى مكونات اللياقة البذنية وتحسن بعض المتغيرات الونية الوظيفية

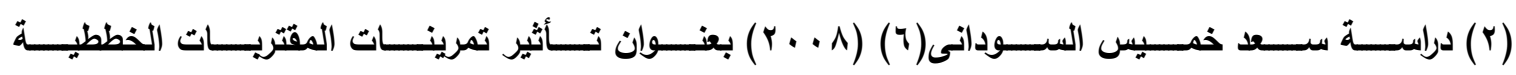

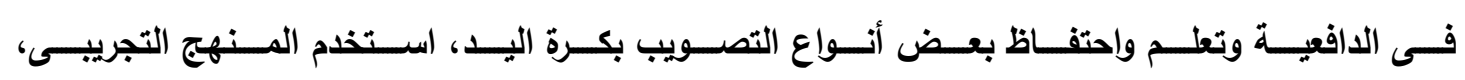

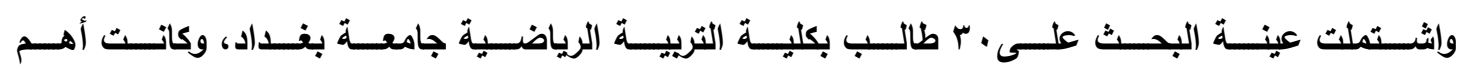

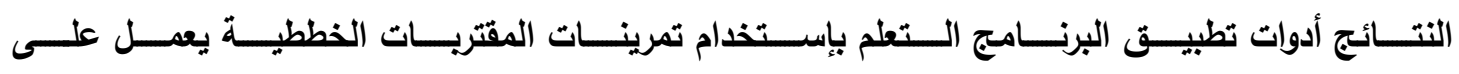

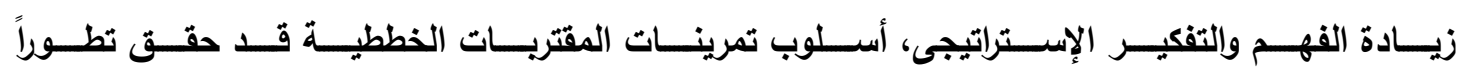
مؤثراً فى مستوى أداء اللعب ويشكل متباين من أسلوب التعليم المتبع.

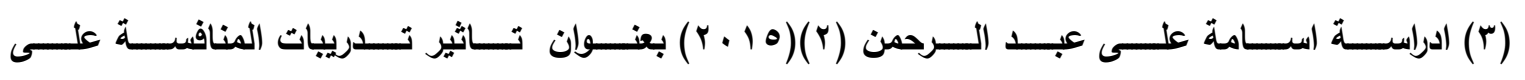

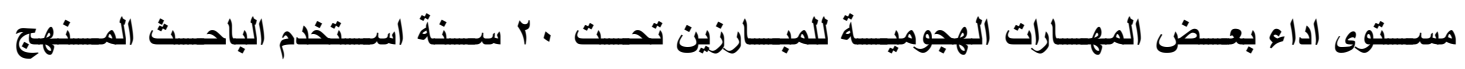

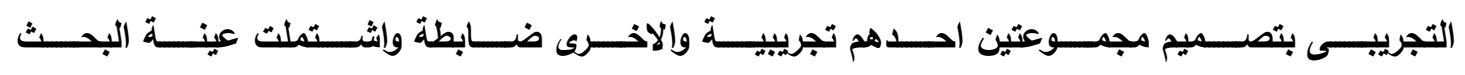

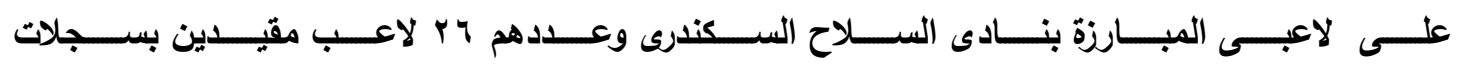

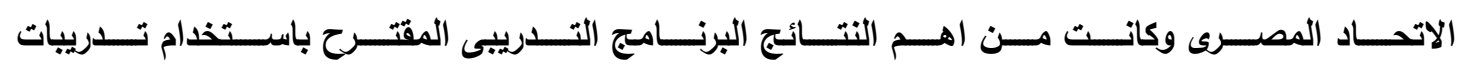

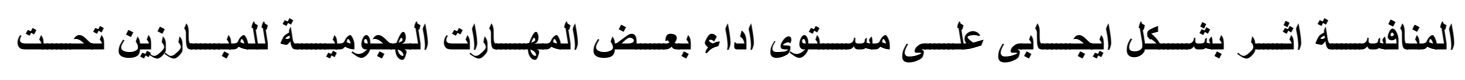
r.

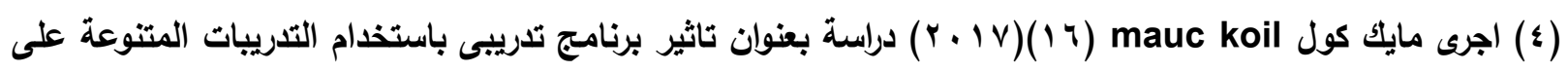

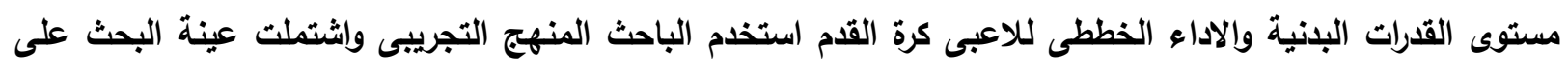

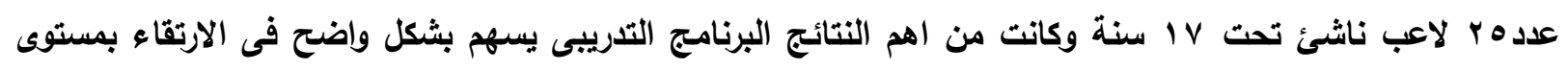
القدرات البدنية والخططية للاعبين

$$
\text { منهرج البحث : البحث }
$$

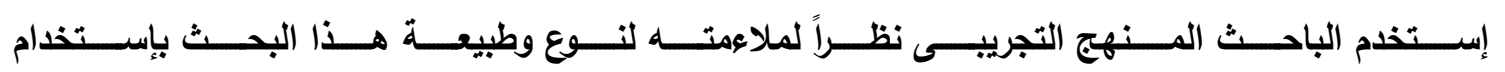

التصميم التجريبى ذو القياس (القبلى والبعدى) للمجموعتين التجريبية والضابطة). مجتمع وعينة البحث :

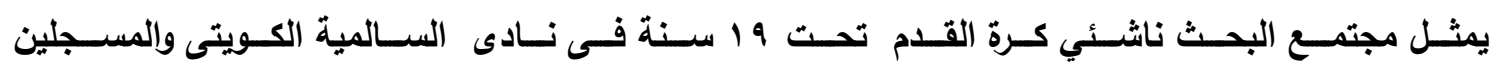

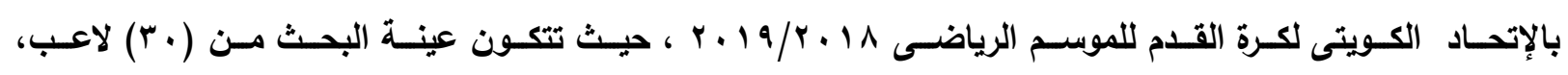

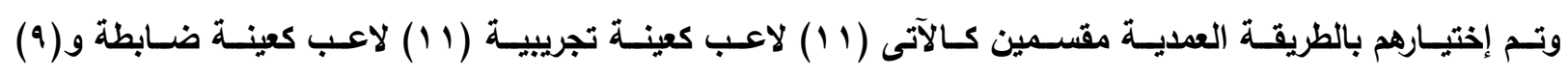

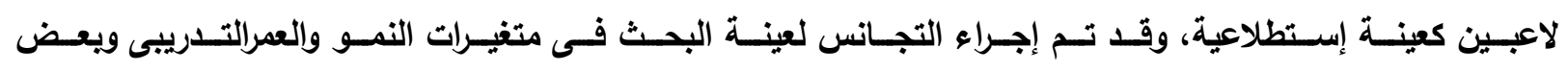

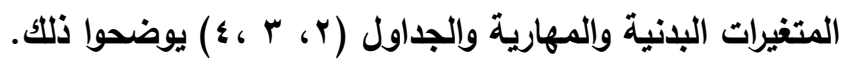




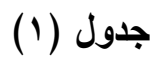

توصيف مجتمع وعينة البحث

\begin{tabular}{|c|c|c|}
\hline العدد & التوصيف & م \\
\hline 11 & العينة التجريبية & 1 \\
\hline 11 & العينة الضابطة & $r$ \\
\hline 9 & لاعبى العينة الاستطلاعية & \\
\hline$r$ & المجموع & \\
\hline
\end{tabular}

تجانس عينة البحث :

- تجانس عينة البحث فى معدلات النمو والعمر التدريبى .

جاول (r) - (r)

المتوسط الحسابى والإنحراف المعيارى ومعامل الإلتواء لعينة البحث

فى متغيرات الطول واللوزن و السن والعمر التدريبى

r. $=\dot{0}$

\begin{tabular}{|c|c|c|c|c|c|}
\hline معامل الالتواء & الانحراف المعيارى & الوسيط & المتوسط & وحدة القياس & المتغير \\
\hline $.0 r$ & Y.M & IV.OH & IV..00r & السنتيمثر & الطول \\
\hline. $.0 \mathrm{~V}$ & P.०q & $0.0 \mu$ & $09.0 \%$ & الكيلوجرام & الوزن \\
\hline$. .7 \wedge-$ &.$r \varepsilon$. & $1 \wedge .0$ & $1 \Lambda .0 \varepsilon$ & السنة & السن \\
\hline .r.to- & $.0 \leq$ & Y.77 & 1.99 & السنة & العمر التدريبى \\
\hline
\end{tabular}

يتضح من جدول (Y) أن جميع قيم معاملات الالتواء لعينة البحث قيد انحصرت مابين (YI)، مما يعنى وقوع جميع البيانات تحت المنحنى ألاعتدالي، ويؤكد على تجانس عينة البحث ككل في بعض متغيرات متغيرات الطول والوزن و

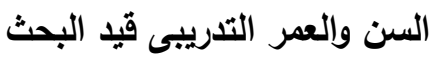

تجانس عينة البحث فى المتغيرات البدنية 


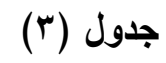

المتوسط الحسابى والإنحراف المعيارى ومعامل الإلتواء لعينة البحث

فى بعض المتغيرات البدنية

\begin{tabular}{|c|c|c|c|c|c|c|}
\hline الالتواء معامل & المعيارى & الوسيط & المتوسط & القياس & الغرض من & الإختبارات \\
\hline-91 & 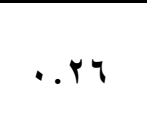 & T.Y. & T.Y. . & ثنانيه & الإلتقالية & اختبار عدو · سم من الوقوف \\
\hline$. .01-$ &.$v 1$ & $\wedge . .$. & $\Lambda .00$ & عدد & تحمل الأداء & سويدى خلال ـ اثل الكرير الكرة مقعد \\
\hline . tro & . r rv & V.०. & $v 1.001$ & ثانيه & رشاقة & اختبار الجرى الزجزاجى بارو \\
\hline$\cdot . r q$ &.$r_{1}$ & M... & $r 1 \ldots$ & 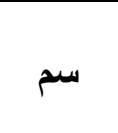 & العضرة & اختبار الوثب العريض من \\
\hline$\ldots .0 \leqslant-$ &. .00 & $0.1 \mathrm{rr}$ & O0.YI. & ثانيه & السرعة & اختبار جرى · سم ×0مرات \\
\hline$. . r r-$ & r.r. & r.lrs & rr.101 & عدد & تحمل القوة & اختبار الجلوس من الرقود \\
\hline. .00 &..$\wedge \wedge$ & .ro. & Y.00. & 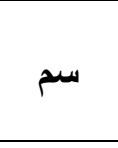 & المرونة & اختبار ثنى الجذع أماما أسفل \\
\hline $1.00-$ & $\ldots 9$ &..$\wedge \wedge$ & $1 . \wedge \wedge$ & دقيقه & التحمل العام & اختبار الجرى · .^^م \\
\hline
\end{tabular}

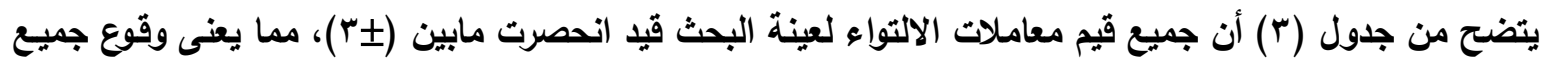
البيانات تحت المنحنى ألاعتدالي، ويؤكد على تجانس عينة البحث ككل في بعض المتثيرات البدنية قيد البحث تجانس عينة البحث فى الأداءات المهارية المندمجة قبد البحث 


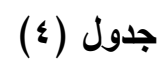

المتوسط الحسابى والانحراف المعيارى ومعامل الالتواء لعينة البحث

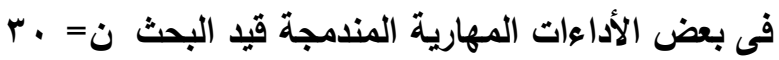

\begin{tabular}{|c|c|c|c|c|c|c|}
\hline معامل الالتواء & المعيارى الانحراف & الوسيط & المتوسط & |وحده القياس & & الإختبارات \\
\hline $1 . Y \leq$ &. $.1 \mathrm{~V}$ & $0 . . r$ & $0 . Y_{1}$ & $\dot{H}$ & زمن الأداء & \multirow{2}{*}{ الإستلام ثم التمرير } \\
\hline.$v V$ &. .19 & 1.91 & 1.09 & درجة & دقة التمرير & \\
\hline 1.77 & $.0 \leqslant$ & 0.90 & $0 . \leqslant \varepsilon$ & $\dot{H}$ & زمن الأداء & \multirow{2}{*}{ استلام ثم الجري بالكرة ثم } \\
\hline I.r & $1 . v$. & 1.99 & 1.00 & درجة & دقة التمرير & \\
\hline. $.1 r$ &. .00 & 0.91 & $0.0 \mathrm{~V}$ & $\stackrel{ث}{ث}$ & زمن الأداء & \multirow{2}{*}{ الإستلام ثم المراوغة ثم } \\
\hline$\cdots \varepsilon$ &.$\vee \vee \wedge$ & 1.90 & 1.9. & درجة & دقة التمرير & \\
\hline .00 & $\cdots \leqslant 0$ & 1.90 & $r . \leqslant 0$ & $\stackrel{ث}{ث}$ & زمن الأداء & \multirow{2}{*}{ الإستلام ثم التصويب } \\
\hline .71 & 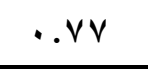 & r... & 1.11 & درجة & دقة التصويب & \\
\hline .70 & . ro & 0.00 & $0 . \wedge 0$ & $\dot{ث}$ & زمن الأداء & \multirow{2}{*}{ الإستلام ثم الجرى ثم } \\
\hline 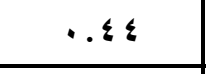 & .74 & 1.99 & 1.7 & درجة & دقة التصويب & \\
\hline .00 &..$r \Lambda$ & 0.70 & 0.90 & $\dot{H}$ & زمن الأداء & \multirow{2}{*}{ الإستلام ثم المراوغة ثم } \\
\hline$. r \cdot-$ & צ & 1.99 & 1.10 & درجة & دقة التصويب & \\
\hline
\end{tabular}

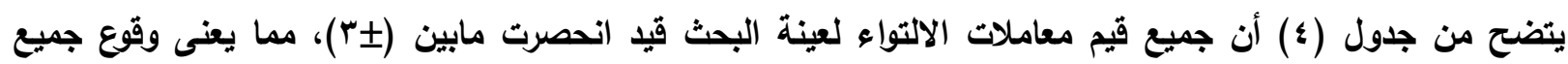

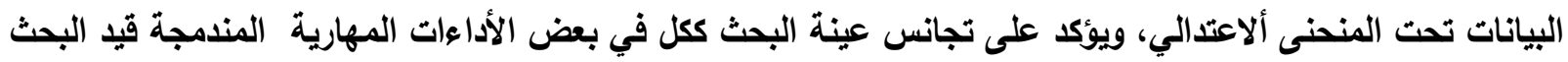
قام الباحث بأجراء التكافؤ بين مجموعتى البحث ( التجريبية - الضابطة ) في المتغيرات الأساسية المستخذمة قيد البحث

كما هو موضح بالجدول رقم (•)

\section{جدول (0) (0)}

دلالة الفروق بين متوسطي القياس القبلى لاى المجموعتين

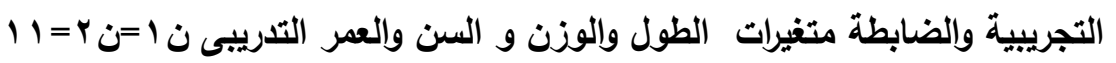

\begin{tabular}{|c|c|c|c|c|c|c|c|}
\hline \multirow{2}{*}{ قيمة } & \multirow{2}{*}{ المتوسطين } & \multicolumn{2}{|c|}{ المجموعة الضابطة } & \multicolumn{2}{|c|}{ المجموعة التجريبية } & \multirow{2}{*}{ والقياس } & \multirow{2}{*}{ الإختبارات } \\
\hline & & $\varepsilon^{ \pm}$ & 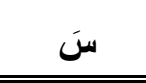 & $\varepsilon^{ \pm}$ & 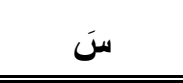 & & \\
\hline .00 & $r \ldots r$ & 17.047 & 191.00 & IV.OTY & iv..0or & السنتيمتر & الطول \\
\hline $1 . r \varepsilon$ & $. \cdot v \cdot 1-$ & T.rY & T.YTI & 0.04 & 09.04 & الكيلوجرام & الوزن \\
\hline.$r V$. & .r.r & 11.00 & IN.TY & 11.0. & $11.0 \%$ & السنة & السن \\
\hline. .7 & $. .1 \leqslant$ & 1.19 & 1.10 & Y.74 & 1.99 & السنة & العمر التتريبي \\
\hline
\end{tabular}


يتضح من الجدول (ه) عدم وجود فروق ذات دلالة إحصائية عند مستوى معنوية ه ه... فى متغيرات الطول

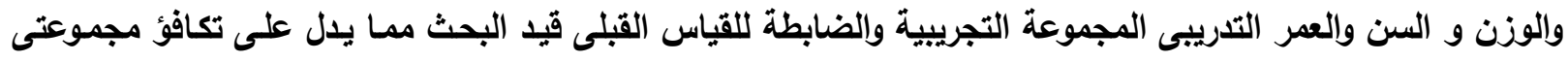

$$
\text { جدول (†) }
$$

دلالة الفروق بين متوسطي القياس القبلى لاى المجموعتين

التجريبية والضابطة للمتنيرات البدنية قيد لبحث ن ا=ن ب=

\begin{tabular}{|c|c|c|c|c|c|c|c|}
\hline \multirow{2}{*}{ قيمة } & \multirow{2}{*}{ الفتوق بين } & \multicolumn{2}{|c|}{ المجموعة الضابطة } & \multicolumn{2}{|c|}{ المجموعة التجريبية } & \multirow{2}{*}{ القياس } & \multirow{2}{*}{ الإختبارات } \\
\hline & & $\varepsilon^{ \pm}$ & سَن & $\varepsilon^{ \pm}$ & سَن سن & & \\
\hline $.0 \leqslant$ & $.79-$ & .00 & $7 . \wedge 1$ & .94 & T.Y. . & ثانيه & الوتبار عدو · سٓم من \\
\hline $1.0 \leqslant$ & $1 . r r$ &. .70 & V.ru & $\cdots v 1$ & 1.00 & عدد & مقعد سويدى خلال • اثلى اثلى أكرة على \\
\hline .10 & $1.9 \cdot 1-$ & 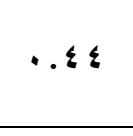 & $V Y . \varepsilon O r$ &.$r V$ & $v 1.001$ & ثانيه & اختبار الجرى الزجزاجى \\
\hline. .70 & $1 . \vee \wedge \vee$ & 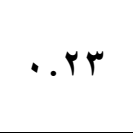 & $r \cdot \Lambda . r \mid r$ & $\cdot r_{1}$ & $r 1 \ldots$ & 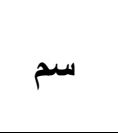 & اختبار الوثب العريض من \\
\hline.$\wedge 0$ & $1.910-$ &. ro $^{\circ}$ & $0 V .1$ Yo &. .00 & $00 . r_{1}$ & ثانيه & اختبار جرى · ·rم ×0مرات \\
\hline .74 & 1.07 & $1 . \wedge 9$. & $r 1.091$ & T.rY & $r .101$ & عدد & اختبار الجلوس من الرقود \\
\hline. ro & $\because r \leq q$ & $\because v^{\circ}$ & $r \cdot r \cdot \varepsilon$ &..$\wedge \wedge$ & Y.००. & 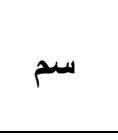 & أستبار ثنى الجذع أماما \\
\hline$\cdot . \leqslant 0$ & $\ldots r Q-$ & $.9 \wedge r$ & 1.9 .0 & $\ldots 9$ & $1 . \wedge \wedge$. & دقيقه & اختبار الجرى · ، ^م \\
\hline
\end{tabular}

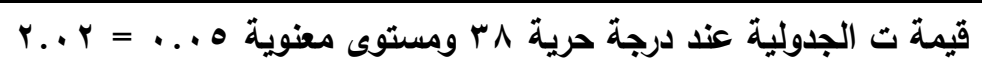

يتضح من الجدول (†) عام وجود فروق ذات دلالة إحصائية عند مستوى معنوية ه ... في للمتغيرات البدنية بين المجموعة التجريبية والضابطة للقياس القبلى قيد البحث مما يدل على على تكافؤ مجموعتى البحث . 


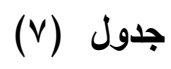

دلالة الفروق بين متوسطي القياس القبلى لاى المجموعتين

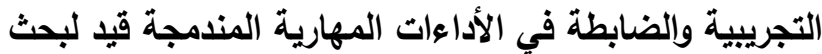

\begin{tabular}{|c|c|c|c|c|c|c|c|}
\hline \multirow{2}{*}{ قيمة } & \multirow{2}{*}{ المتوسطين بين } & \multicolumn{2}{|c|}{ المجموعة الضابطة } & \multicolumn{2}{|c|}{ المجموعة التجريبية } & \multirow{2}{*}{ وحده القياس } & \multirow{2}{*}{ الإختبارات } \\
\hline & & $\varepsilon^{ \pm}$ & سَ & $\varepsilon^{ \pm}$ & سَ س & & \\
\hline $1 . .7$ &. .19 & .11 & $0 . . r$ &. $.1 \mathrm{~V}$ & $0 . M_{1}$ & زمن الأداء & \multirow{2}{*}{ الإستلام ثم التمرير } \\
\hline 1.11 & . & $\cdot . \wedge \wedge$ & $1 . r r$ &. .19 & 1.09 & دقة التمرير & \\
\hline $1 . \vee \wedge$ &..$\leqslant \varepsilon-$ & .rr & $0 . \wedge 1$ & $.0 \leqslant$ & $0 . \leqslant \varepsilon$ & زمن الأداء & \multirow{2}{*}{ الإستلام ثم الجرى التمرير } \\
\hline . rr & . rr & 1.rr & 1.9. & $1 . v$. & 1.00 & دقة التمرير & \\
\hline.$v_{0}$ &.$M_{1-}$ & r & $0 . \vee \wedge$ &. .00 & $0.0 \mathrm{~V}$ & زمن الأداء & \multirow{2}{*}{ الإستلام ثم المراوغة } \\
\hline$\cdot . \wedge \wedge$ & $. .1-$ & .90 & r... &.$\vee \wedge$ & 1.9. & دقة التمرير & \\
\hline$\cdot . \wedge$. & $. r-$ & .00 & T.70 & $\therefore \leqslant 0$ & r. $\leqslant 0$ & زمن الأداء & \multirow{2}{*}{ الإستلام ثم } \\
\hline . &. $.1 r$ & .00 & 1.20 &.$v V$ & 1.11 & دقة التصويب & \\
\hline .04 & $. .1 \leq-$ & .00 & 0.99 & . tro & 0.10 & زمن الأداء & \multirow{2}{*}{ ثالإستلام ثم الجرى } \\
\hline $1 . v V$ & $.10-$ & . rr & 1.20 &. .74 & 1.7 & دقة التصويب & \\
\hline..$\wedge \wedge$ & $\ldots 0-$ & $\ldots 0 \leqslant$ & $7 .$. &..$\mu \wedge$ & 0.90 & زمن الأداء & \multirow{2}{*}{ الإستلام ثم المراوغة } \\
\hline 1.70 & $\cdot . \wedge$ & . & $1 . V V$ & & 1.10 & دقة التصويب & \\
\hline
\end{tabular}

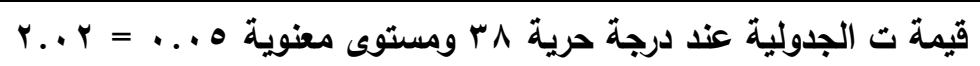

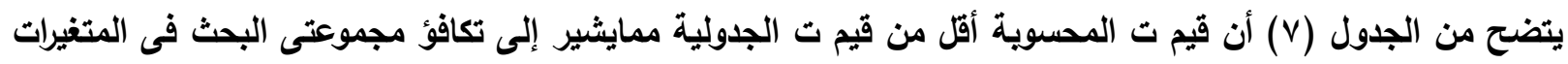

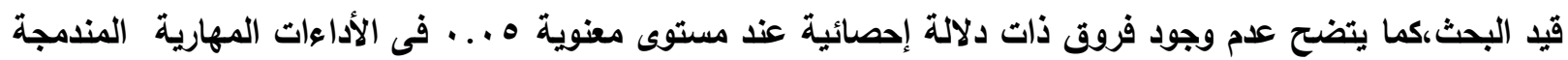
بين المجموعة التجريبية والضابطة للقياس القبلى قيد البحث مما يدل على تكافؤ مجموعتى البحث

$$
\text { وسائل وأدوات جمع البيانات : }
$$

$$
\text { ا - المسح المرجعي }
$$

ومن خلال المسح المرجعى للمراجع العلمية والداسات والبحوث السابقة مثل (عمرو أبو المجد وجمال النمكى

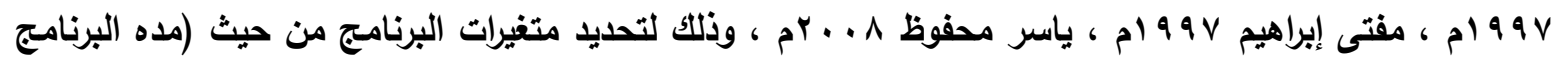

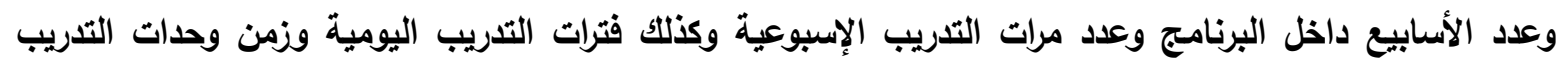

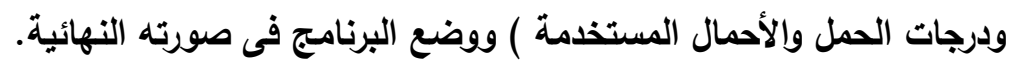

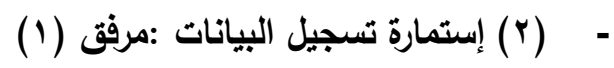


إستمارة تسجيل البيانات الخاصة بعينة البحث وأشتملت على البيانات الثخصية للاعب و نتائج الإختبارات الخاصة بالأداعات المهارية المندمجة ، السن ، الطول ، الوزن ، العمر التدريبى الإختبارات المستخدمة : - إختبارات الأداعات المهارية المندمجة والصفات البدنية : مرفق (ץ) توصل الباحث إلى الإختبارات التى يمكن الاستفادة منها والتى تقيس الأداءات المهارية المندمجة والصفات

$$
\text { البدنية قيد البحث . توصل }
$$

الأجهزة المستخدمة :

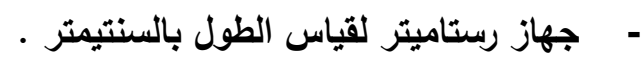
- - ميزان طبى معاير لقياس الوزن بالكيلوجرام ل

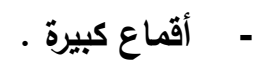

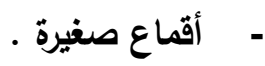
-

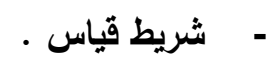
- ساعة إيقاف الكترونية لأقرب (1/ ل . . 1ث) . -

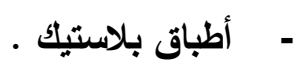

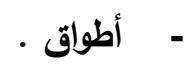

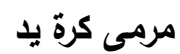
خطوات تنفيذ البحث:

قـام الباحـث بـإجراء القيـاس القبلـى عـى عيـــة الدراســة الأساسـية (التجريبيـة) فـى الأداعات المهاريـة المندمجـة

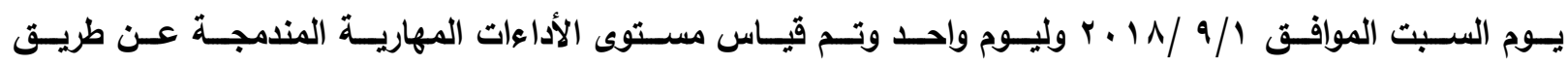
إختبارات الأداعات المهارية المندمجة وذلك بملاعب نادى السالمية الرياضى بدولة الكويت وله

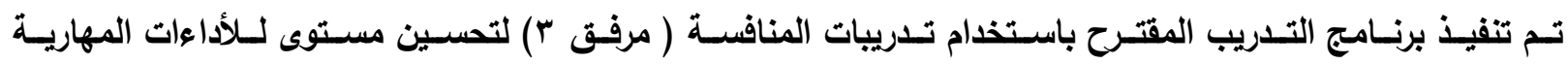

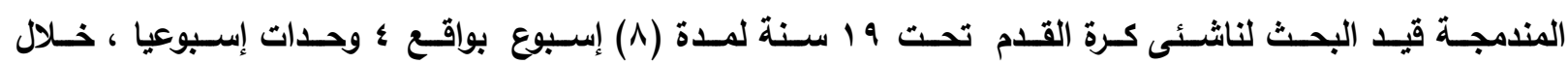

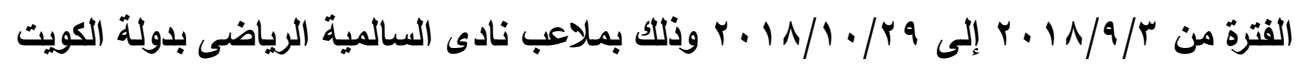

تم إجراء القياس البعدى على عينة الدراسـة الأساسية (تجريبية) فى الأداعات المهاريـة المندمجة يوم الخميس الموافق

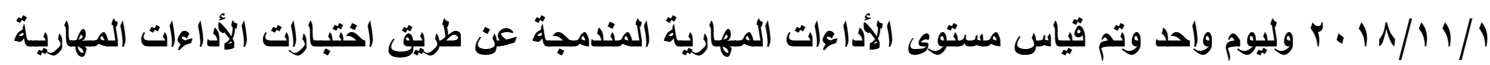

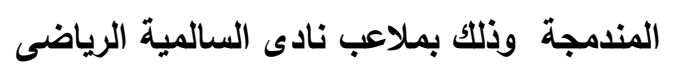

وقام الباحث بتجميع البيانات وجدولتها تمهياً لمعالجتها إحصائياً وعرضها ومناقشتها وإستخلاص النتائج منها.

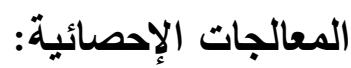


تم إجراء المعالجات الإحصائية باستخدام برنامج الحزم الإحصائية Spss باستخدام الحاسب الآلى وذلك من خلال

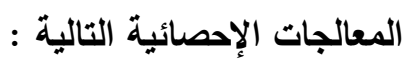

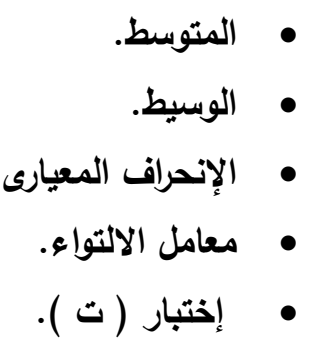

• معامل الإرتباط لبيرسون. / ن نسب التحسن

عرض ومناقشة النتائج عرض نتائج قياسات الأداءات المهارية المندمجة قيدالبحث :

جدول (ir)

دلالة الفروق بين متوسطي القياسين (القبلي والبعدى) لاى مجموعة

التجريبية للمتغيرات قيد البحث

\begin{tabular}{|c|c|c|c|c|c|c|c|}
\hline \multirow{2}{*}{ قيمة } & \multirow{2}{*}{ المترسط بين } & \multicolumn{2}{|c|}{ القياس البعدى } & \multicolumn{2}{|c|}{ القياس القبلى } & \multirow{2}{*}{ وحده القياس } & \multirow{2}{*}{ الإختبارات } \\
\hline & & $\varepsilon^{ \pm}$ & سَ & $\varepsilon \pm$ & سََ & & \\
\hline 9.02 & 0.75 & 0.42 & 5.17 & 0.62 & 5.92 & زمن الأداء & \multirow{2}{*}{ الإستلام ثم التمرير } \\
\hline 14.62 & $3.00^{-}$ & 0.60 & 4.45 & 0.69 & 1.45 & دقة التمرير & \\
\hline 2.61 & 0.28 & 0.31 & 5.90 & 0.48 & 6.18 & زمن الأداء & \multirow{2}{*}{ الإستلام ثم الجرى التمرير } \\
\hline 7.90 & $2.30^{-}$ & 0.72 & 4.10 & 0.77 & 1.80 & دقة التمريز & \\
\hline 17.00 & 2.37 & 0.32 & 3.79 & 0.51 & 6.16 & زمن الأداء & \multirow{2}{*}{ الإستلام ثم المراوغة } \\
\hline 11.69 & $2.60^{-}$ & 0.61 & 4.50 & 0.64 & 1.90 & دقة التمرير & \\
\hline 17.26 & 0.56 & 0.34 & 3.85 & 0.37 & 4.42 & زمن الأداء & \multirow{2}{*}{ الإستلام ثم } \\
\hline 13.54 & $2.65^{-}$ & 0.59 & 4.35 & 0.73 & 1.70 & دقة التصويب & \\
\hline 22.20 & 0.66 & 0.26 & 4.66 & 0.32 & 5.32 & زمن الأداء & \multirow{2}{*}{ ثالإستلام ثم التصويب } \\
\hline 12.70 & $2.65^{-}$ & 0.67 & 4.15 & 0.61 & 1.50 & دقة التصويب & \\
\hline 21.11 & 0.61 & 0.25 & 5.71 & 0.32 & 6.32 & زمن الأداء & \multirow{2}{*}{ الإستلام ثم المراوغة } \\
\hline 10.97 & $2.45^{-}$ & 0.79 & 4.10 & 0.49 & 1.65 & دقة التصويب & \\
\hline
\end{tabular}

قيمة ت الجدولية عذ مستوى معنوية ه. 


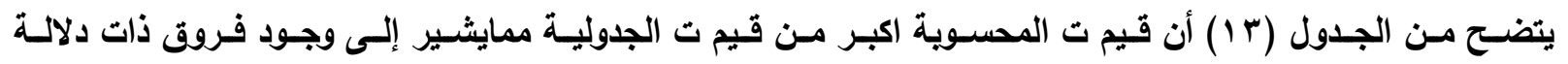

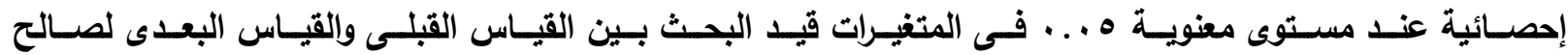

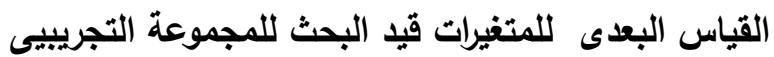

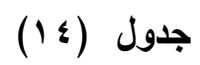

دلالة الفروق بين متوسطي القياسين ( القبلي والبعدى) لاى مجموعة

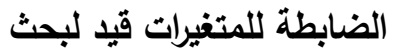

$11=\dot{0}$

\begin{tabular}{|c|c|c|c|c|c|c|c|}
\hline \multirow{2}{*}{ قيمة } & \multirow{2}{*}{ المتوسطين } & \multicolumn{2}{|c|}{ القياس البعدى } & \multicolumn{2}{|c|}{ القياس القبلى } & \multirow{2}{*}{ وحده القياس } & \multirow{2}{*}{ الإختبارات } \\
\hline & & $\varepsilon^{ \pm}$ & 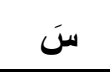 & $\varepsilon^{ \pm}$ & سَنَ & & \\
\hline 3.04 & 0.27 & 0.64 & 5.68 & 0.69 & 5.95 & زمن الأداء & \multirow{2}{*}{ الإستلام ثم التمرير } \\
\hline 3.94 & $1.05-$ & 0.65 & 3.00 & 0.94 & 1.95 & دقة التمرير & \\
\hline 4.13 & $0.51-$ & 0.44 & 6.47 & 0.26 & 5.96 & زمن الأداء & \multirow{2}{*}{ الإمتلام ثم الجرى } \\
\hline 4.40 & $1.10^{-}$ & 0.88 & 2.85 & 0.64 & 1.75 & دقة التمرير & \\
\hline 12.09 & 1.67 & 0.40 & 4.36 & 0.55 & 6.02 & زمن الأداء & \multirow{2}{*}{ الإستلام ثم المراوغة } \\
\hline 4.25 & $0.95^{-}$ & 0.73 & 3.00 & 0.76 & 2.05 & دقة التمرير & \\
\hline 91.00 & 0.23 & 0.34 & 4.28 & 0.34 & 4.51 & زمن الأداء & \multirow{2}{*}{ الإستلام ثم } \\
\hline 7.61 & $1.60^{-}$ & 0.51 & 3.45 & 0.81 & 1.85 & دقة التصويب & \\
\hline 8.95 & 0.37 & 0.30 & 5.02 & 0.35 & 5.39 & زمن الأداء & \multirow{2}{*}{ الإستلام ثم الجرى } \\
\hline 5.90 & $1.45-$ & 0.89 & 3.20 & 0.64 & 1.75 & دقة التصويب & \\
\hline 5.17 & 0.25 & 0.31 & 6.17 & $\mathbf{0 . 3 5}$ & 6.41 & زمن الأداء & \multirow{2}{*}{ الإستلام ثم المراوغة } \\
\hline 4.86 & $1.20^{-}$ & 0.81 & 3.15 & 0.76 & 1.95 & دقة التصويب & \\
\hline
\end{tabular}

قيمة ت الجدولية عذ مستوى معنوية ه.. = 1.

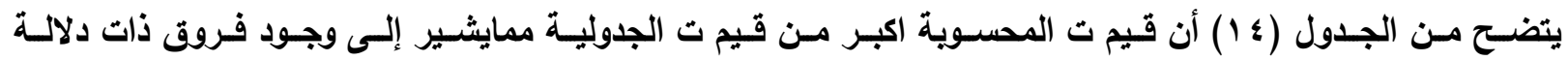

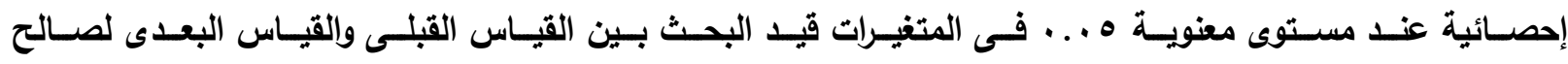
القياس البعدى للمتغيرات قيد البحث للمجموعة الضابطة 
جدول (10)

دلالة الفروق بين متوسطي القياس البعدى لاى المجموعتين

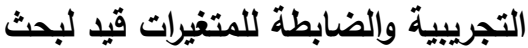

\begin{tabular}{|c|c|c|c|c|c|c|c|}
\hline \multirow{2}{*}{ قيمة } & \multirow{2}{*}{ المتوسطين } & \multicolumn{2}{|c|}{ المجموعة الضابطة } & \multicolumn{2}{|c|}{ المجموعة التجريبية } & \multirow{2}{*}{ وحده القياس } & \multirow{2}{*}{ الإختبارات } \\
\hline & & $\varepsilon^{ \pm}$ & سََ & $\varepsilon^{ \pm}$ & سَنَ & & \\
\hline 2.96 & $0.51-$ & 0.64 & 5.68 & 0.42 & 5.17 & زمن الأداء & \multirow{2}{*}{ الإستلام ثم التمرير } \\
\hline 7.31 & 1.45 & 0.65 & 3.00 & 0.60 & 4.45 & دقة التمرير & \\
\hline 4.76 & $0.57-$ & 0.44 & 6.47 & 0.31 & 5.90 & زمن الأداء & \multirow{2}{*}{ الإستلام ثم الجرى } \\
\hline 4.94 & 1.25 & 0.88 & 2.85 & 0.72 & 4.10 & دقة التمرير & \\
\hline 5.00 & $0.57-$ & 0.40 & 4.36 & 0.32 & 3.79 & زمن الأداء & \multirow{2}{*}{ الإستلام ثم المراوغة } \\
\hline 7.09 & 1.50 & 0.73 & 3.00 & 0.61 & 4.50 & دقة التمرير & \\
\hline 4.02 & $0.43-$ & 0.34 & 4.28 & 0.34 & 3.85 & زمن الأداء & \multirow{2}{*}{ الإستلام ثم } \\
\hline 5.17 & 0.90 & 0.51 & 3.45 & 0.59 & 4.35 & دقة التصويب & \\
\hline 3.96 & $0.35-$ & 0.30 & 5.02 & 0.26 & 4.66 & زمن الأداء & \multirow{2}{*}{ الإستلام ثم الجرى } \\
\hline 3.80 & 0.95 & 0.89 & 3.20 & 0.67 & 4.15 & دقة التصويب & \\
\hline 5.20 & $0.46^{-}$ & 0.31 & 6.17 & 0.25 & 5.71 & زمن الأداء & \multirow{2}{*}{ الإستلام ثم المراوغة } \\
\hline 3.75 & 0.95 & 0.81 & 3.15 & 0.79 & 4.10 & دقة التصويب & \\
\hline
\end{tabular}

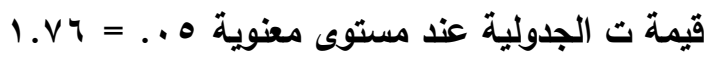

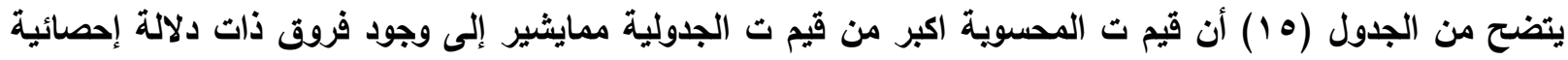

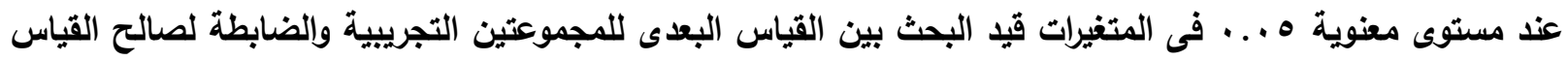

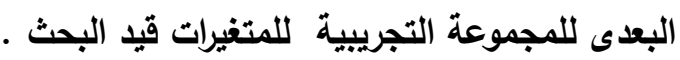

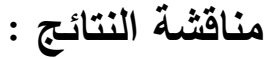

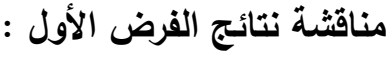
يتضح من الجدول (r ا أن قيم ت المحسوية اكبر من قيم ت الجدولية ممايشير إلى وجود فروق ذات دلالة إحصائية

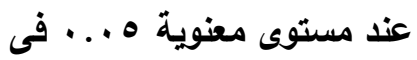
المتغيرات قيل البحث بين القياس القبلى والقياس البعدى لصالح القياس البعدى للمتغيرات قيد البحث للمجموعة التجريبية.

ويرجع الباحث ذلك إلى تدريبات المنافسة والتى تعتمد على استخذام تدريبات تتثابه مع تلك المواقف التى تحدث اثثاء

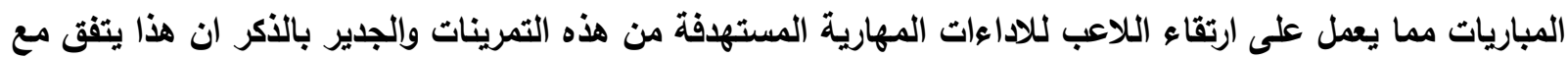




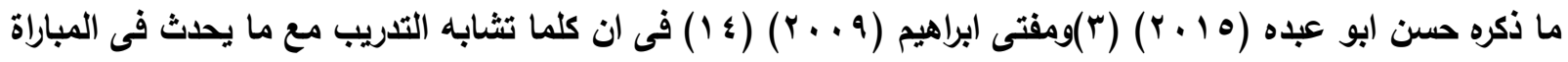

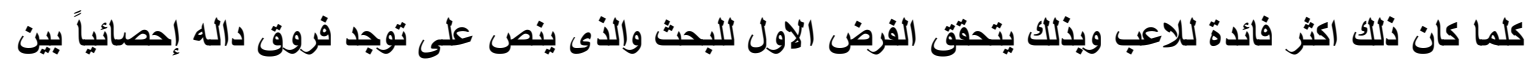
القياسين (القبلى - البعدى) لصالح القياس البعدى للمجموعة التجريبية فى بعض الأداعات المهارية المندمجة لأى لأى عينة البحث مناقشة نتائج الفرض الثانى :

يتضح من الجدول (ع 1) أن قيم ت المحسوية اكبر من قيم ت الجدولية ممايثير إلى وجود فروق ذات دلالة إحصائية عند مستوى معنوية ه ... في المتغيرات قيد البحث بين القياس القبلى والقياس البعدى لصالح القياس البعدى للمتغيرات قيد البحث للمجموعة الضابطة ويرجع الباحث هذا التقام إلى إحتواء البرنامج التدريبى (التقليدى) التى خضعت له المجموعة الضابطة على التى

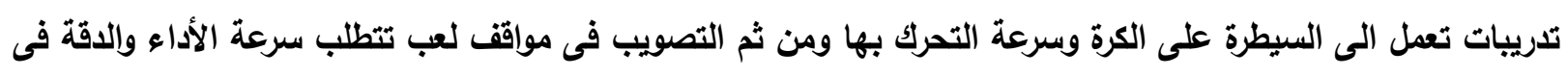

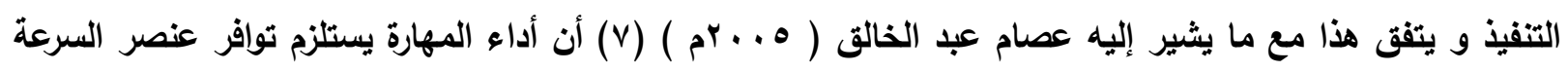

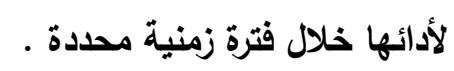
بذلك يتحقى الفرض الذى ينص على :

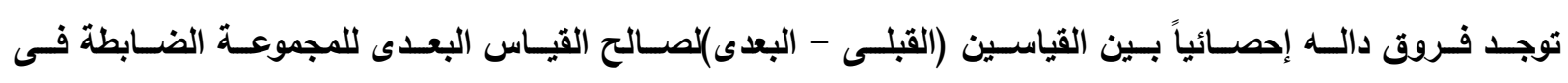

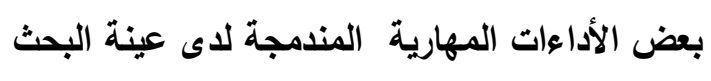
مناقثة نتائج الفرض الثالث : يتضح من الجدول (0 1 ) أن قيم ت المحسوية اكبر من قيم ت الجدولية ممايشير إلى وجود فروق ذات دلالة إحصائية

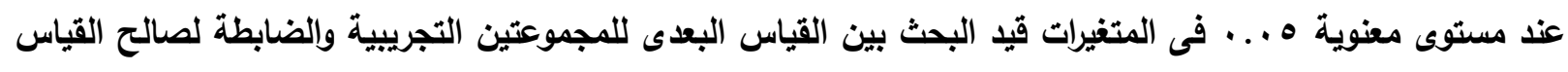

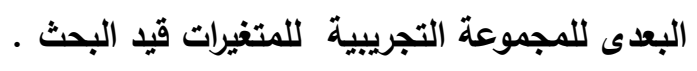

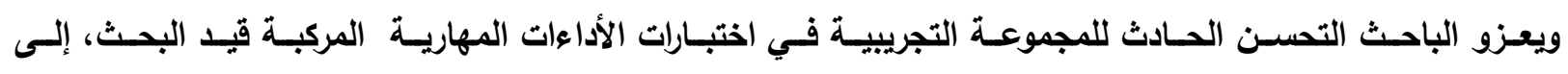

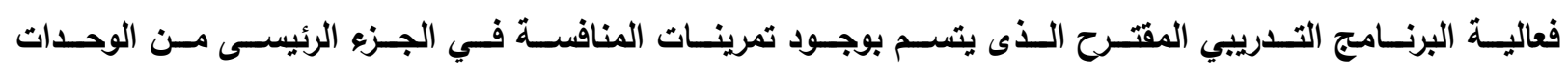

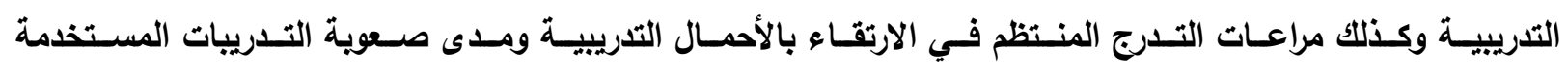

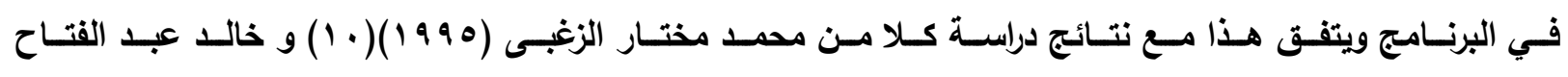

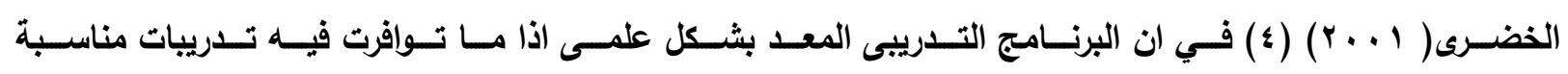

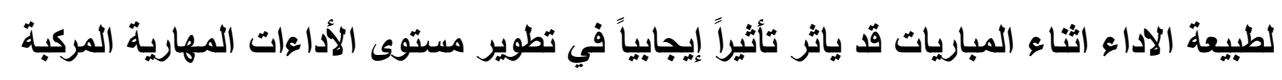
ويذلك يتحقى الفرض الذى ينص على :توجد فروق داله إحصائياً بين القياس البعدى للمجموعتين التجريبية والضابطة لصالح القياس البعدى للمجموعة

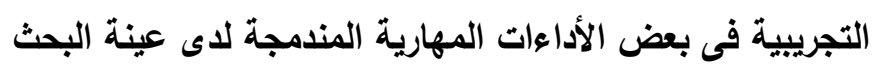


الإستتناجات : (1)

فى ضوء نتائج البحث وفى حدود العينة والمعالجات الإحصائية توصل الباحث للاستنتاجات التالية:

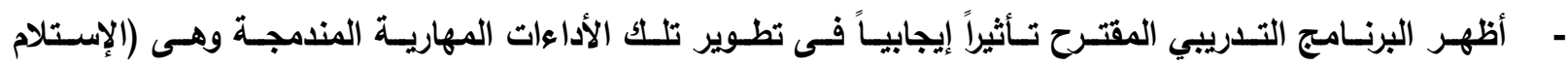

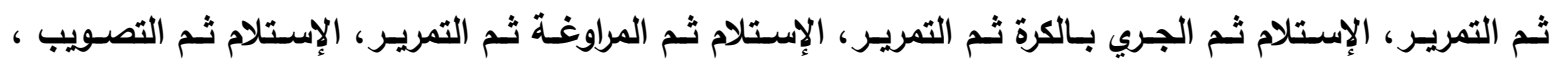

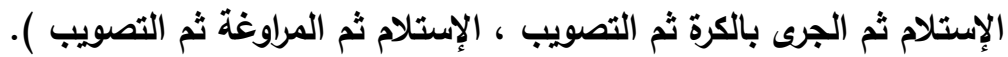

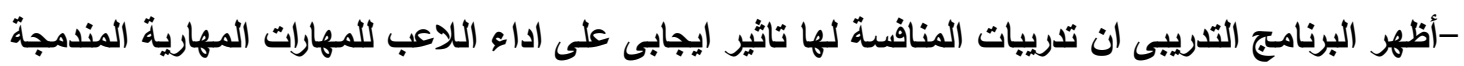
التوصيات : فـ ضوء الإستخلاصـات التى إعتمـدت عليها طبيعة الاراسـة والإجراءات التى تم إتباعها ونتائج التحليل الإحصـائى والإستنتاجات التى تم التوصل إليها يوصى الباحث بالأتى :-

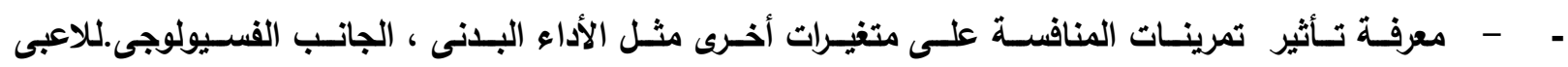
كرة القدم

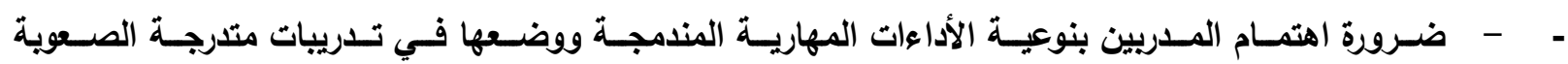

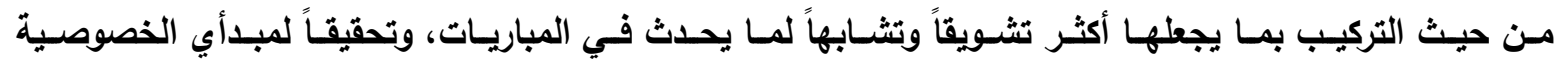
والتنوع. 


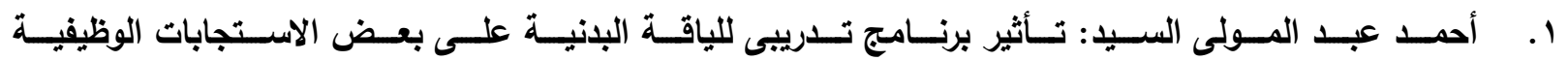

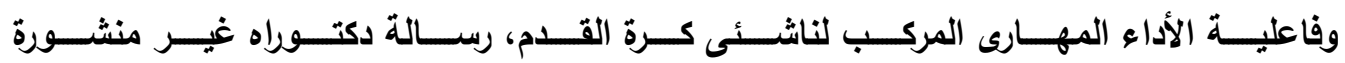

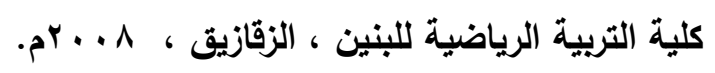

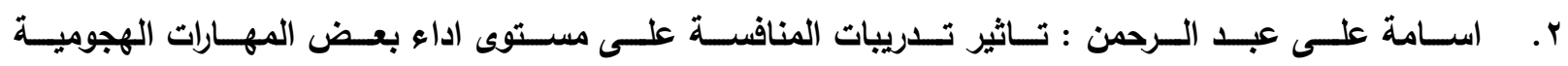

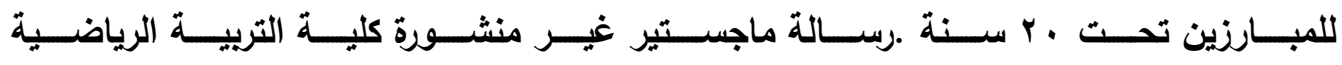

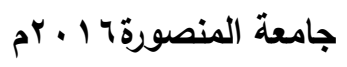

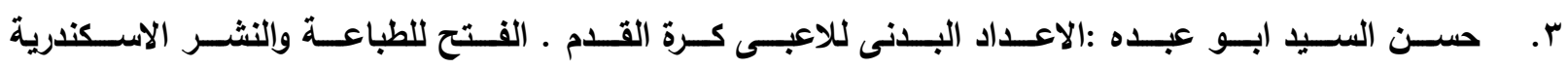

$$
\text { r. } 10
$$

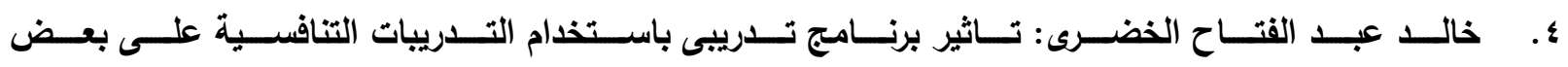

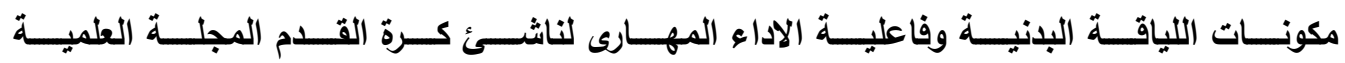

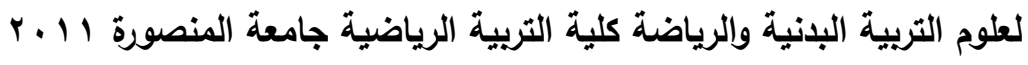

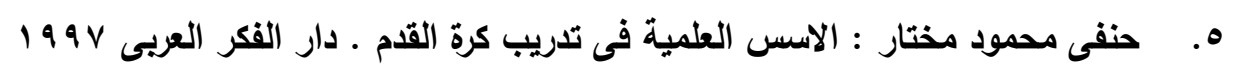

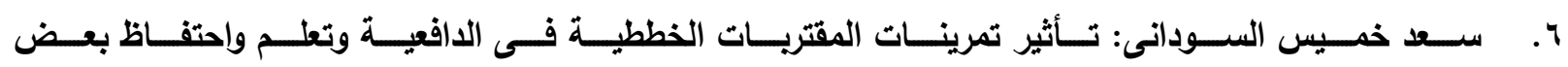

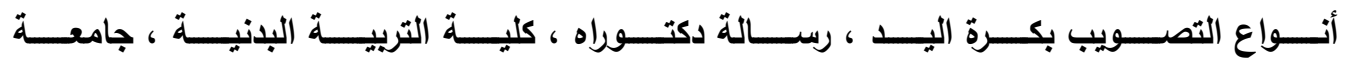

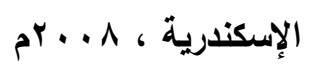

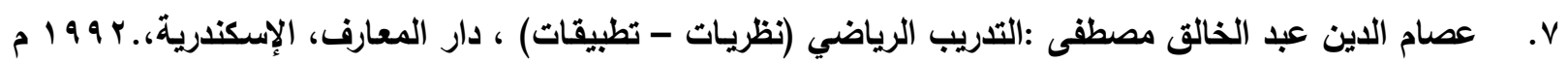
^. عمرو أبو المجد، جمال النمكى: تخطيط برامج تربية وتدريب البراعم و الناثـئين فى كرة القدم ، مركز الكتاب

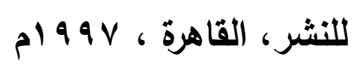

9 . على فهمى البيك: الاتجاهات الحديثة في مجال الاعداد البذنى 9 . . . د درا المعارف الاسكندرية

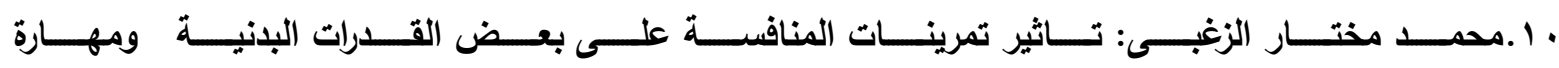

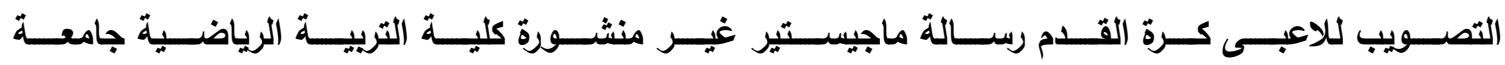

$$
\text { قناة السويس } 1990
$$

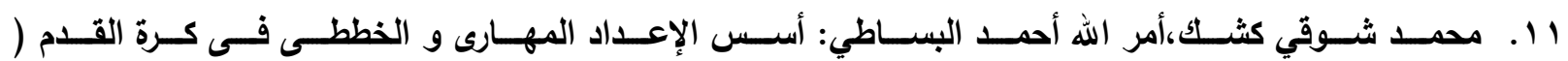

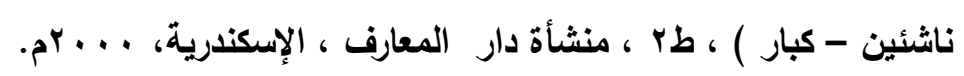

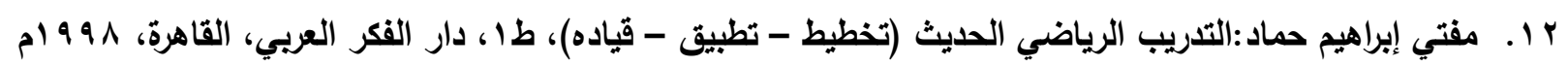

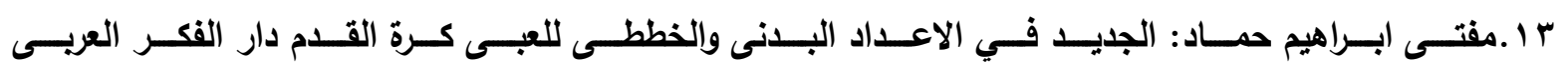

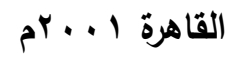

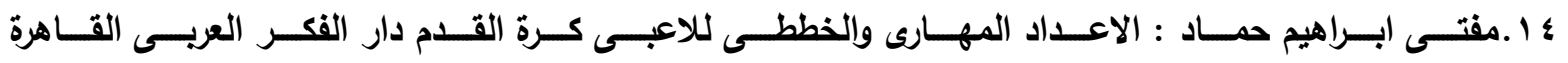




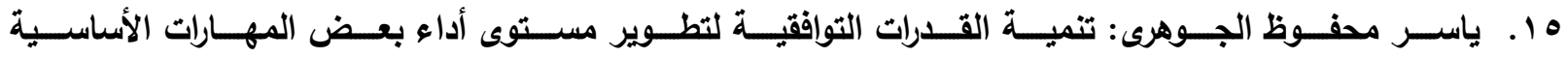

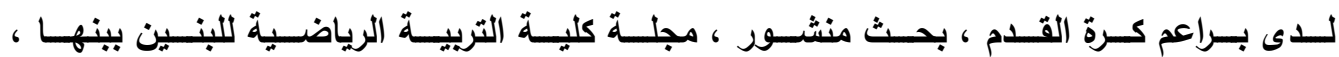

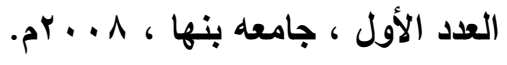

16.mauik coil Impact of

$$
\text { ثانياً المراجع الاجنبية: }
$$

the program Training using various exercises on the level of physical abilities and performance The schematics of football players 2017 


\section{مستخلص البحث}

تأثير استخدام تدريبات المنافسة على أداء بعض المهارات المندمجة للاعبى كرة القدم "حسن سعد مساعد المجمد"

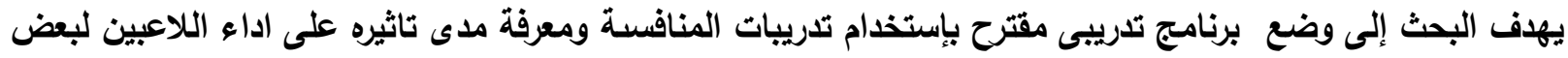

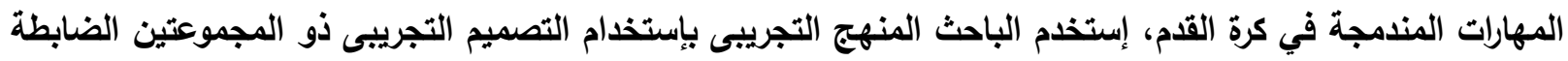
والتجريبية ، حيث بلغ عدد عينة البحث (·•) لاعباً، وتم إختيارهم بالطريقة العدية مقسمين كالآتى (11) لاعب كعينة

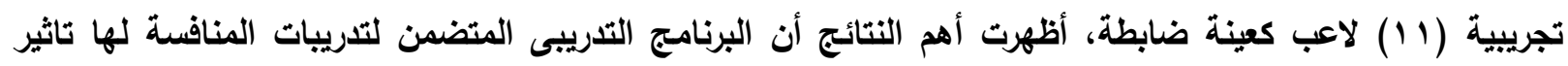
ايجابى على اداء اللاعب للمهارات المهارية المندمجة. الكلمات المفتاحية : تدريبات المنافسة ، المهارات المندمجة 


\section{Abstract \\ Effect of using of competition exercises on the performance of some of the combined skills for football players}

* Hassan Saad Assistant frozen

The aim of the research is to set up proposed training program using competitive Exercises and to identify its effects on performance of players to some of the combined skills in football'the researcher used the experimental method two groups design, the sample was chosen purposively divided as (11) players as experimental sample (11) player as an control one 'most important results showed that the training program that the competition exercises have a positive effect on the player's performance of combined skills.

Keywords: Competition exercises, Combined skills 